\title{
GROWTH AND YIELD OF OKRA (Abelmoschus esculentus L. Moench) AS INFLUENCED BY FERTILIZER APPLICATION UNDER DIFFERENT CROPPING SYSTEMS
}

\author{
Aderemi Isaiah Makinde ${ }^{1,2}$, Kehinde O Oyekale ${ }^{1}$, David S Daramola ${ }^{1}$ \\ ${ }^{1}$ Department of Agriculture and Industrial Technology, Babcock University, Ilishan-Remo, Nigeria \\ ${ }^{2}$ Department of Agriculture, Federal College of Agriculture, Ibadan, Nigeria \\ *corresponding author: makindeaderemi30@gmail.com
}

\begin{abstract}
Reduction in agricultural land with increasing population has led to a need to combine more than one crop to maximize limited land resources and thus require an improvement. A field experiment was conducted during the growing seasons of 2019 in two locations in Southwest Nigeria to assess the effect of cropping system and fertilizer application on the yield of okra intercropped with jatropha. The experiment was a split-plot arrangement in a Randomized Complete Block design, replicated three times. Fertilizer types were the main plots (NPK, Organic, Organic + NPK (50:50) and control while the cropping systems (sole okra, sole Jatropha and their intercrop) were sub-plot. Data were collected to determine okra growth includes: plant height, number of leaves/ plant, leaf area, and the yield by number of days to $50 \%$ flowering, number of fruits/ ha, fruit yield and fruiting duration. Jatropha growth parameters taken include plant height $(\mathrm{cm})$, number of leaves/plant. Results showed that okra can be intercropped with jatropha without reducing its performance. Growth of jatropha and okra yield was significantly better in fertilized plots than in unfertilized plots, with complimentary use of organic and inorganic fertilizer producing the best results.
\end{abstract}

Keywords: Fertilizer, Growth, Intercropping, Jatropha, Okra, Yield.

http://dx.doi.org/10.21776/ub.agrise.2022.022.1.5

Received 14 December 2020

Accepted 25 January 2022

Available online 31 January 2022

\section{INTRODUCTION}

A cropping system is an aspect of farming system where two or more crops are grown together on the same plot but farmers uniquely manage the resources to satisfy human needs for food, fibre, various products, monetary income etc (Okigbo, 1982). Intercropping, a significant component of cropping system, is a system of managing two or more economic species growing together for at least a portion of the companion crop's life cycle and thus experience inter-specific competition among themselves (Usman, 2001). It plays a significant role in peasant food production in advanced and emerging countries (Adeoye et al., 2005). It gives higher yield than sole crops, more excellent yield stability, and efficient mineral resources (Seran and Brintha, 2009).

Despite the advantages of monocropping, almost all peasant farmers in the developing world still practice intercropping because it allows positive interaction among crops (Wolfe, 2000), greater production of crops, reduce insect-pest incidence, reduce transfer of diseases (Ramert, 2002) and

CITATION: Makinde, A. I., Oyekale, K. O., Daramola, D. S., (2022). GROWTH AND YIELD OF OKRA (Abelmoschus esculentus L. Moench) AS INFLUENCED BY FERTILIZER APPLICATION UNDER DIFFERENT CROPPING SYSTEMS, Agricultural Socio-Economics Journal, $22(1), \quad 29-36 \quad$ DOI: http://dx.doi.org/10.21776/ub.agrise.2022.022.1.5 
create good crop environment like greater soil and water conservation potential (Gilley et al., 2002).

Okra production in Nigeria, either sole or in crop combination, has increased due to its high nutritional value. It provides important sources of protein, vitamin $\mathrm{A}$ and $\mathrm{C}$, carbohydrate, calcium, potassium, magnesium, and other minerals, which are often lacking in people's diet. Its medicinal ability can be seen in the treatment of peptic ulcer and as source of plasma replacement in man's body fluid (Olawuyi et al., 2012).

In the intercropping situation involving okra with other component crop varieties, even thou taller component intercepts major share of the light, productivity was still better under intercropping as evident in all the works reviewed, (Ijoyah and Usman, 2013). Where land equivalent ratio (LER) values were all above 1.00 , indicating yield advantage and the suitability and compatibility of okra as a potential intercrop for farmers and can therefore be recommended as a potential intercrop for farmers in Nigeria. Of all the intercropping system investigated over the years, farmers rarely considered Jatropha probably because of the lack of knowledge about the inherent potential of the crop as soil fertility restorer, repellent agent or as an alternative to energy to drive the economy.

Over the years, fossil fuels supply most of the energy requirements of industrialized nations, which has contributed majorly to greenhouse gas (GHG) emissions that threaten to seriously affect ecosystems through human-induced climate change, which compromises survival of humanity (Cotula $e t$ al., 2008). Jatropha, a non-food perennial shrub well adapted to semiarid regions, can serve as a new alternative for biofuel production, minimizing adverse effects on the environment and food supply (Caroline et al., 2009).

Jatropha or Physic nut Jatropha curcas is one of the essential oil seed crop belonging to the Euphorbiaceae family same as rubber tree and cassava. Jatropha seeds can be processed into lesser polluting biodiesel than fossil diesel to provide light and cooking fuel for poor rural families. To achieve success in an intensive cropping like intercropping, the challenge of limited resources will have to be addressed headlong. Some of the major constraints identified to be responsible for low production of arable crops include poor soil fertility, high cost and unavailability of inorganic fertilizer, difficulty in getting enough quantity for large scale production and delay in the release of the essential mineral nutrients for immediate use of the plant (Olawuyi $e t$ al., 2010). Hence, fertilizers to sustain cropping systems on most tropical soils is necessary due to their generally low nutrient status (Adetunji, 1991).

Nutrients can be supplied through organic or inorganic sources. Organic manure usually have relatively lower nutrient contents with slower rates of mineralization and nutrient forms that are not immediately available to plants (Makinde et al., 2015). Nutrient concentrations from inorganic fertilizers are higher, usually in plant-available forms, and are released quickly for plant to use. Mineral fertilizers have been more suitable when growing short-time maturing vegetables (Makinde et al., 2001) than long-time maturing crops like Jatropha. Therefore, to maximize the production of these essential crops, it is important to verify their compatibility and environmental conditions that could enhance their performance. The study was conducted to assess fertilizer type's effects on the growth of okra as a sole crop or when intercropped with Jatropha.

\section{RESEARCH METHODS}

\section{Experimental Sites}

The experiment was conducted during the growing seasons of 2019 in Institute of Agricultural Research and Training (I.A.R\&T) stations in Ibadan and Ikenne, Southwestern Nigeria. Ibadan is located in Nigeria's Rainforest-Savannah Transitional vegetation zone on Latitude $07^{0} 23^{1} \mathrm{~N}$, Longitude $03^{0}$ $50^{1} \mathrm{E} ; 160 \mathrm{~m}$ above sea level. The soil belongs to TypicKanhaplustalf (Soil survey Staff, 1975) and was locally classified as Iwo series in the order Alfisol by Oluwatosin, (2009) as described by Symth and Montgomery, (1962). The soil is generally well drained and the $\mathrm{pH}$ of the soils show moderately acid to weakly acidic soil. It is generally sandy and so is subject to leaching. Ikenne research station is in Rainforest belt. It lies within latitude $6^{\circ} \mathrm{N}$ and $8^{\circ} \mathrm{N}$ and longitude $2^{\circ} \mathrm{E}$ and $5^{\circ} \mathrm{E}$. Ibadan has mean total rainfall of $1128.0 \mathrm{~mm}$, while Ikenne has mean annual rainfall ranging from $1725.9 \mathrm{~mm}$. Rainfall distribution in both sites is bimodal with June and September peaks, respectively (Table 2). The mean maximum temperature is $30.50{ }^{\circ} \mathrm{C}$ (Ibadan) and $30.92^{\circ} \mathrm{C}$ (Ikenne) however, while Ikenne is in the rain forest agro ecology, Ibadan is in the fringes of the rain forest and derived savanna of Nigeria (Demographia, 2015).

\section{Soil sampling and sample preparations}

Several core samples will be obtained from $0-15 \mathrm{~cm}$ depth over the experimental site, collated samples will be bulked and a composite sample will be obtained for soil analysis before planting begins. The soil samples will be air-dried, crushed and passed through a $2 \mathrm{~mm}$ sieve. Similarly soil samples 
will be taken from each sub-sub plot at the end of the cropping season for laboratory assay for physical and chemical properties assessment. According to International Institute of Tropical Agriculture (1979) procedures, routine analyses that will be carried out include the following: Soil $\mathrm{pH}$ will be determined in distilled water at 1:1 (soil : water). Percentage organic matter will be calculated by multiplying percentage organic carbon by a factor of 1.72 (Broadbent, 1953). Total $\mathrm{N}$ will be determined by the micro-Kjedahl digestion method. Available $\mathrm{P}$ will be determined by Bray's P1 test; using 0.03 $\mathrm{NH} 4 \mathrm{~F}$ in $0.02 \mathrm{~N} \mathrm{HCl}$ as the extractant and measuring extracted $\mathrm{P}$ colorimerically at $660 \mathrm{~nm}$ by the molybdenum blue method (Bray and Kurtz, 1945). Exchangeable bases will be determined by extraction with neutral normal NH4OAC at a soil: solution ratio of 1:10. The exchangeable $\mathrm{Ca}, \mathrm{K}, \mathrm{Mg}$, and $\mathrm{Na}$ was extracted with $1 \mathrm{~N}$ ammonium acetate, $\mathrm{pH}$ 7.0, and measured with a flame photometer. Magnesium was determined by atomic absorption spectrophotometry.

\section{Experimental design and crop arrangement}

Jatropha curcas var Linnaeus seeds was obtained from Forestry Research Institute of Nigeria (FRIN) and Okra seeds (LD 88), spineless, late maturing cultivar was sourced from the National Institute for Horticultural Research and Training (NIHORT), Ibadan, Nigeria. Organic compost made from cassava peel and poultry waste at ratio $2: 1$ was used while NPK (20:10:10) fertilizers was sourced from Ibadan. The experiment was a split-plot arrangement in a Randomized Complete Block design with 12 treatment combinations, replicated three times. Fertilizer types was the main plots while the cropping systems was sub-plot. The treatment consist of four fertilizer sources (applied at the rate of $75 \mathrm{kgN} / \mathrm{ha}$ ) sourced from NPK, Organic, Organic + NPK (50:50) and control (no fertilizer) and three cropping systems comprising of sole okra, sole Jatropha and okra intercropped with Jatropha. Jatropha hedges was established by direct seeding at the onset of rainy season at a spacing of $2.5 \times 1.2 \mathrm{~m}$ in the main plot of $7.5 \times 3.6 \mathrm{~m}$ giving rise to 16 plants/plot. Okra was planted eight weeks after planting Jatropha at the recommended spacing of 30 x $50 \mathrm{~cm}$ (NIHORT, 1985) in the sole and in the alleys $(2.5 \times 1.2 \mathrm{~m})$ of Jatropha where okra will be planted, 2-3 seeds/hole, at a depth of $2-3 \mathrm{~cm}$ and will later be thinned to one plant per stand 2 weeks after planting, WAP. Weeding will be done manually before the introduction of okra and at 5 weeks after planting (WAP) okra based on the recommendation of Temnotfo and Henry, (2017) who identified 5 WAP as the critical period of weed interference in okra which represents the equality point of control and interference, which determines the equality of increasing or decreasing crop yield in response to competitive conditions. Organic compost was applied a week before planting Jatropha while N: P: $\mathrm{K}$ fertilizer was applied in splits: first at 2 WAP and at $6 \mathrm{WAP}$ okra in the appropriate plots.

\section{Data collected and analysis}

Data were collected from 4 plants per plot from inner rows from 4 weeks after planting, WAP, and at 2 weeks intervals to determine okra growth, including plant height, number of leaves per plant, and leaf area. Leaf area was estimated by the non-destructive method of Olasantan and Salau (2008). The leaf area was calculated by the estimated regression equation between leaf area $(\mathrm{Y})$ and leaf length $(\mathrm{X})$ is: $\mathrm{Y}=$ $386.93+40.56 \mathrm{X}(\mathrm{r}=0.91)$. Two fully expanded leaves from five sample plants was used whose mean length will represent X. Okra yield was assessed by: number of days to attain $50 \%$ flowering, number of fruits per ha, fruit yield and fruiting duration. Jatropha plant growth parameters were taken at full establishment on the field before introducing okra at 8 WAP and at bimonthly intervals, including plant height $(\mathrm{cm})$ and number of leaves/plant. Data were subjected to Analysis of variance (ANOVA) using SAS (SAS, 1990) and the Duncan Multiple Range Test (DMRT) was used for means separation at $5 \%$ probability.

\section{RESULTS AND DISCUSSION}

The result of the soil's physical and -chemical properties for both sites before trial establishment showed that the soil is strongly acidic (4.67 and 5.48) and the textural class of the soils in both sites was sand (Table 1$)$. The total Nitrogen were low $(0.3$ and $0.6 \mathrm{~g} / \mathrm{kg}$ ) as they were below the critical level of $1.6-2.0 \mathrm{~g} / \mathrm{kg}$. Organic carbon was also low (1.7 and 3.8 ) as they were below the critical level of 10-14 $\mathrm{g} / \mathrm{kg}$ while available phosphorus content was moderate as it fell within the critical level of 7-20 $\mathrm{mg} / \mathrm{kg}$. The K status of the soil used at both Ibadan and Ikenne were low ( 0.11 and 0.17 respectively) as they were both below the critical level of $0.31 \mathrm{c}$ $\mathrm{mol} / \mathrm{kg}$ (FFD 2012). Hence, both sites are expected to show good response to fertilizer application. However, compost was slightly alkaline with a higher amount of $\mathrm{N}, \mathrm{K}$, and organic $\mathrm{C}$ with respect to the soil but lower $\mathrm{P}$ value.

Table 1: Pre-cropping soil analysis and Compost nutrient composition

\begin{tabular}{|c|c|c|c|}
\hline \multirow{2}{*}{ Properties } & Ibadan & Ikenne & Compost \\
\hline & & & \\
\hline $\mathrm{pH}\left(\mathrm{H}_{2} \mathrm{O}\right)$ & 4.67 & 5.48 & 8.30 \\
\hline Total N $(\mathrm{g} / \mathrm{kg})$ & 0.3 & 0.6 & 2.90 \\
\hline $\begin{array}{l}\text { Organic matter } \\
(\mathrm{g} / \mathrm{kg})\end{array}$ & 2.92 & 6.54 & 129.86 \\
\hline $\begin{array}{l}\text { Organic } \\
(\mathrm{g} / \mathrm{kg})\end{array}$ & 1.7 & 3.8 & 75.50 \\
\hline
\end{tabular}




\begin{tabular}{|c|c|c|c|}
\hline & Ibadan & Ikenne & Compost \\
\hline $\begin{array}{ll}\begin{array}{l}\text { Available } \\
(\mathrm{mg} / \mathrm{kg})\end{array} & \mathrm{P}\end{array}$ & 18.36 & 13.64 & 0.42 \\
\hline \multicolumn{4}{|l|}{ Exchangeable } \\
\hline \multicolumn{4}{|l|}{$\begin{array}{l}\text { Bases } \\
(\mathrm{cmol} / \mathrm{kg})\end{array}$} \\
\hline $\mathrm{Ca}$ & 4.86 & 6.43 & 5.59 \\
\hline $\mathrm{Mg}$ & 4.55 & 1.54 & 1.42 \\
\hline $\mathrm{K}$ & 0.11 & 0.17 & 1.85 \\
\hline $\mathrm{Na}$ & 0.46 & 0.48 & 0.38 \\
\hline $\mathrm{Al}+\mathrm{H}$ & 0.14 & 0.12 & ND \\
\hline ECEC & 10.12 & 8.74 & ND \\
\hline Base & 98.62 & 98.63 & ND \\
\hline \multicolumn{4}{|l|}{ Saturation (\%) } \\
\hline \multicolumn{4}{|l|}{$\begin{array}{l}\text { Micronutrients } \\
(\mathrm{mg} / \mathrm{Kg})\end{array}$} \\
\hline $\mathrm{Mn}$ & 30.60 & 22.65 & 497.00 \\
\hline $\mathrm{Fe}$ & 3.00 & 1.25 & 662.00 \\
\hline $\mathrm{Cu}$ & 0.50 & 0.91 & 25.20 \\
\hline $\mathrm{Zn}$ & 2.03 & 1.84 & 68.71 \\
\hline $\begin{array}{l}\text { Particle size } \\
(\mathrm{g} / \mathrm{kg})\end{array}$ & & & \\
\hline Sand & 938.0 & 938.0 & ND \\
\hline Silt & 14.0 & 14.0 & ND \\
\hline Clay & 48.0 & 48.0 & ND \\
\hline Textural class & Sand & Sand & ND \\
\hline
\end{tabular}

ND: not determined

Table 2: Monthly rainfall, minimum and maximum temperatures, relative humidity and sunshine hours in 2019

\begin{tabular}{|c|c|c|c|c|c|c|c|c|c|c|c|}
\hline \multirow{5}{*}{$\begin{array}{l}\text { Ibadan } \\
\text { Month }\end{array}$} & \multirow{5}{*}{$\begin{array}{l}\text { Mean } \\
\text { Max. } \\
\text { Temp } \\
\left({ }^{0} \mathrm{C}\right)\end{array}$} & \multirow{5}{*}{$\begin{array}{l}\text { Mean } \\
\text { Min. } \\
\text { Temp } \\
\left({ }^{0} \mathrm{C}\right)\end{array}$} & \multirow{5}{*}{$\begin{array}{l}\text { Mean } \\
\text { R.H } \\
(\%)\end{array}$} & \multirow{5}{*}{$\begin{array}{l}\text { Mean } \\
\text { Sunshine } \\
\text { hours } \\
\text { (hr/day) }\end{array}$} & \multirow{5}{*}{$\begin{array}{l}\text { Mean } \\
\text { monthly } \\
\text { rainfall } \\
(\mathrm{mm})\end{array}$} & \multicolumn{5}{|l|}{ Thkequneents } & \multirow{4}{*}{ height } \\
\hline & & & & & & Mean & \multirow{2}{*}{\multicolumn{2}{|c|}{$\begin{array}{l}\text { Mean Mean } \\
\text { Max. NuMdiner }\end{array}$}} & & & \\
\hline & & & & & & monthly & & & of & Plant & \\
\hline & & & & & & rainfall & \multicolumn{3}{|c|}{ Temp leaTersplant } & $(\mathrm{cm})$ & \\
\hline & & & & & & Ikemple site & $\left({ }^{\circ} \mathrm{C}\right)$ & 8 WAP & 16 & 8 & 16 \\
\hline January & 33 & 21 & 62 & 7 & 7 & 35.7 & 35 & 22 & WAP & WAP & WAP \\
\hline February & 34 & 22 & 65 & 7.3 & 14 & 98.8 ino & 34 & 23 & & & \\
\hline March & 34 & 23 & 79 & 7.8 & 26 & sestems & 34 & 21 & & & \\
\hline April & 34 & 22 & 72 & 7 & 149 & sole & 31 & 13.226 & 44.69 & 23.77 & 63.10 \\
\hline May & 33 & 21 & 89 & 6.8 & 151 & 148.3 & 28 & 22 & & & \\
\hline June & 31 & 20 & 88 & 7.4 & 184 & Interchop & 27 & 12,21 & 41.29 & 24.14 & 61.56 \\
\hline July & 30 & 22 & 82 & 7.6 & 94 & 112.1 & 27 & $\mathrm{Ns}_{21}$ & Ns & Ns & Ns \\
\hline August & 30 & 23 & 80 & 6.8 & 144 & Fyttilizer & 33 & 23 & & & \\
\hline September & 31 & 20 & 86 & 7 & 186 & Côntrol & 27 & $10225 b$ & 25.46 & 21.76 & 44.50 \\
\hline October & 32 & 21 & 64 & 7 & 162 & 406.7 & 27 & 22 & $\mathrm{~b}$ & $\mathrm{a}$ & $\mathrm{c}$ \\
\hline November & 34 & 21 & 54 & 7 & 11 & NoB & 34 & $10246 b$ & 34.00 & 21.34 & 57.58 \\
\hline December & 34 & 21 & 48 & 7 & 0 & 0 & 34 & 21 & $\mathrm{~b}$ & $\mathrm{a}$ & $\mathrm{b}$ \\
\hline Total & & & & & 1128.0 & Argatsite & & $18.00 \mathrm{a}$ & 67.21 & 28.55 & 83.10 \\
\hline Mean & 32.50 & 21.42 & 72.42 & 7.14 & 102.5 & 156.9 & 30.92 & 21.75 & $\mathrm{a}$ & & $\mathrm{a}$ \\
\hline \multirow{2}{*}{\multicolumn{6}{|c|}{$\begin{array}{l}\text { Source: Meteorological Station, Institute of } \\
\text { Agricultural Research and Training, Ibadan. }\end{array}$}} & Organic & + & $12.54 \mathrm{a}$ & 45.29 & 24.18 & 64.13 \\
\hline & & & & & & $\begin{array}{l}\text { Inorganic } \\
(50: 50)\end{array}$ & & $\mathrm{b}$ & $\mathrm{b}$ & $\mathrm{a}$ & $\mathrm{b}$ \\
\hline \multirow{4}{*}{\multicolumn{6}{|c|}{$\begin{array}{l}\text { Effect of cropping system and fertilizer sources } \\
\text { on the growth of Jatropha curcas. } \\
\text { Jatropha had similar growth attributes as a sole crop } \\
\text { and when intercropped with okra, indicating the } \\
\text { compatibility of both crops at both sites. (Table } 3 \text { ). }\end{array}$}} & $\mathrm{C}^{*} \mathrm{~F}$ & & ns & ns & ns & $\mathrm{ns}$ \\
\hline & & & & & & Ibadan site & & & & & \\
\hline & & & & & & & & & & & \\
\hline & & & & & & $\begin{array}{l}\text { Cropping } \\
\text { systems }\end{array}$ & & & & & \\
\hline
\end{tabular}

Although, jatropha produced taller plants with more leaves as a sole crop relative to intercropping, its performance is not significantly better than when grown as an intercrop. This is similar to the work of Geply et al., (2011) who observed that intercropping of jatropha with arable crops does not negatively affect the height of jatropha. Fertilizer application significantly $(p<0.05)$ had positive effect on the growth of jatropha in Ikenne site when compared with unfertilized plants. Reinforced the previous work of Ravi Kant and Surjeet, (2013), where fertilizer had significant effect on the growth parameters of Jatropha curcas, unlike in Ibadan site where both fertilized and control plots had similar growth performance, probably because of lower $\mathrm{pH}$ value which is far from $\mathrm{pH} \geq 6$ necessary for optimum availability of minerals for growing crops as reported by Robert (2013). Jatropha raised with organic fertilizer significantly had better growth than all the other fertilizer sources comparable with one another. Better results shown by organic fertilizer may be due to its ability to improve soil structure for nutrient and water retention and the lower $\mathrm{C} / \mathrm{N}$ ratio which eases mineralization. Jatropha growth at Ikenne was at least $50 \%$ better than that in Ibadan. However, there was no significant interaction between the cropping system and type of fertilizer applied at both sites.

Table 3: Effect of cropping system and fertilizer sources on the growth of Jatropha curcas

\section{Thkesnnents}




\begin{tabular}{|c|c|c|c|c|c|}
\hline \multirow{3}{*}{$\begin{array}{l}\text { Sole } \\
\text { Intercrop }\end{array}$} & & 6.08 & 11.73 & 12.86 & 22.67 \\
\hline & & 5.42 & 9.33 & 13.31 & 20.00 \\
\hline & & ns & ns & $\mathrm{ns}$ & ns \\
\hline \multicolumn{6}{|l|}{ Fertilizer } \\
\hline Control & & $6.17 \mathrm{a}$ & $7.75 a$ & 13.98 & 17.99 \\
\hline NPK & & $4.71 \mathrm{a}$ & 11.50 & $\begin{array}{l}\mathrm{a} \\
11.67\end{array}$ & $\begin{array}{l}\mathrm{a} \\
22.62\end{array}$ \\
\hline & & & $\mathrm{a}$ & $\mathrm{a}$ & $\mathrm{a}$ \\
\hline Organic & & $6.46 a$ & $\begin{array}{l}10.54 \\
\mathrm{a}\end{array}$ & $\begin{array}{l}14.66 \\
a\end{array}$ & $\begin{array}{l}23.12 \\
a\end{array}$ \\
\hline Organic & + & $5.67 \mathrm{a}$ & 12.33 & 12.04 & 21.60 \\
\hline $\begin{array}{l}\text { Inorganic } \\
(50: 50)\end{array}$ & & & $\mathrm{a}$ & $\mathrm{a}$ & $\mathrm{a}$ \\
\hline $\mathrm{C}^{*} \mathrm{~F}$ & & ns & ns & ns & ns \\
\hline
\end{tabular}

WAP $=$ weeks after planting

Effect of cropping system and fertilizer sources on the growth of Okra at 8 WAP

On both sites, the cropping system did not affect okra growth as they had similar growth patterns as a sole crop and under intercropping (Table 4). Number of leaves/plant, leaf area and plant height of okra at the peak of their growth were similar under sole and intercropping unlike the report of Silwana and Lucas (2002) that intercropping reduced vegetative growth of components crops due to high competitive ability of the component crops, except in Ibadan where leaf area of okra under sole cropping, $149.99 \mathrm{~cm}^{2}$, was significantly wider than that under intercrop, 129.73 $\mathrm{cm}^{2}$. Application of fertilizer significantly $(p<$ 0.05 ) improved on the performance of okra in both sites than the unfertilized plants (Omotoso et al., 2018). Okra grown with the complementary use of organic and inorganic fertilizer significantly had better growth in terms of plant height and leaf area expansion and than other fertilizer sources, as confirmed by Akande et al., (2010) where complementary application of 2.5 tonnes of organic manure and $60 \mathrm{~kg} \mathrm{~N}$ as NPK 20-10-10 mostly improved okra growth and yield. However, similar results were obtained with other fertilizer sources in leaf production. Meanwhile, there was no significant interaction between the cropping system and type of fertilizer applied.

Table 4: Effect of cropping system and fertilizer sources on the growth of Okra at $8 \mathrm{WAP}$

\begin{tabular}{lccc} 
Treatments & $\begin{array}{c}\text { Number of } \\
\text { leaves/pla } \\
\mathrm{nt}\end{array}$ & $\begin{array}{c}\text { Leaf } \\
\text { area } \\
\left(\mathrm{cm}^{2}\right)\end{array}$ & $\begin{array}{c}\text { Plant } \\
\text { height } \\
(\mathrm{cm})\end{array}$ \\
\hline Ikenne site & & & \\
$\begin{array}{l}\text { Cropping } \\
\text { systems } \\
\text { Sole }\end{array}$ & 8.43 & 146.19 & 31.77 \\
\hline
\end{tabular}

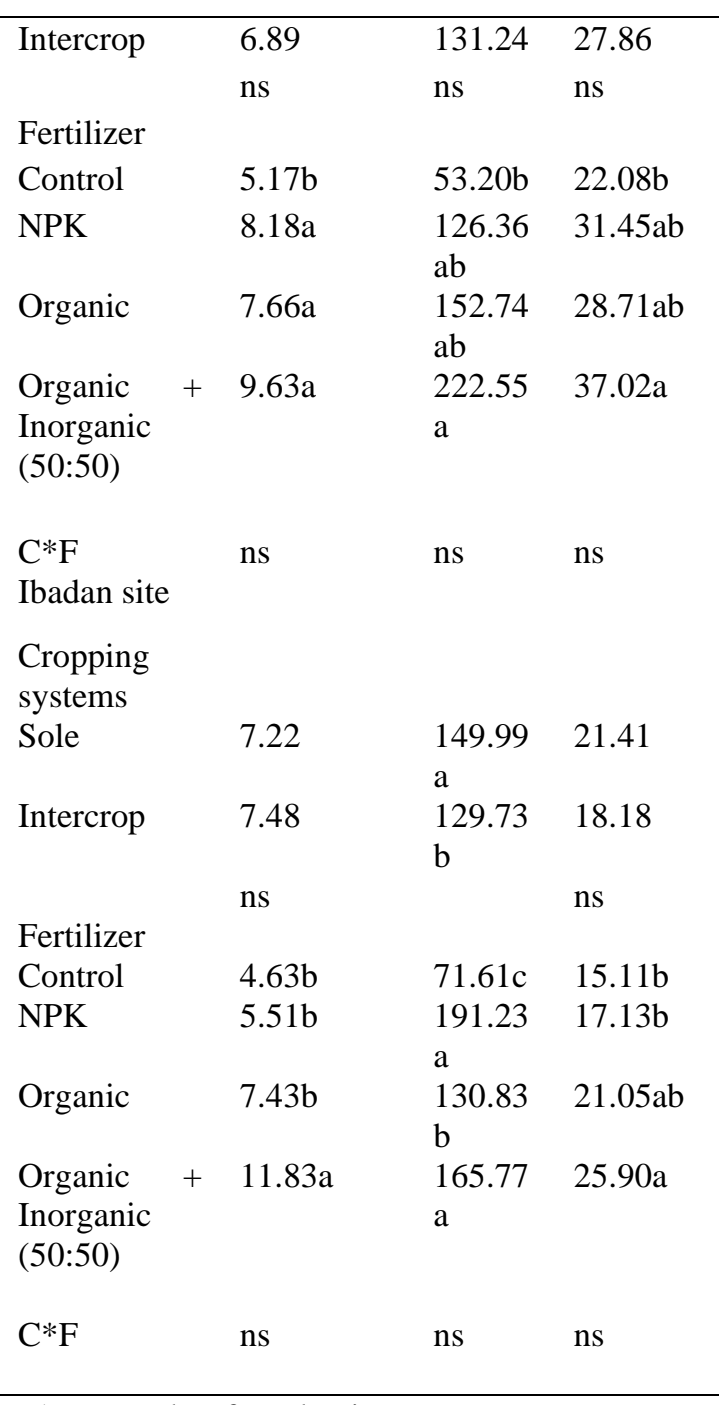

WAP $=$ weeks after planting

Effect of cropping system and fertilizer sources on the yield and yield components of Okra

Okra variety used was a genetically stable variety as the plants flower at the similar time in both locations, under the investigated cropping systems, as seen in the similarity of days to $50 \%$ flowering which is about 60 days from planting (Table 5). Plants grown from organic sources and in combination with inorganic sources significantly flower earlier than other sources in Ibadan. It helped to absorb nutrients for early initiation of the flowering bud and thus help develop more flower within the shortest possible period (Kumar et al. 2017). However, the poor response of okra flowering to fertilizer application in Ikenne may be due to low or poor nutrient release (Mishra et al., 2020). Harvest duration was not affected by cropping system in both sites even though sole crops had higher value but fertilizer application increased duration of okra harvest in both site due to the better availability and uptake of plant nutrients for a longer time of crop growth. While sole cropping 
significantly produced more fruits in Ikenne, number of fruits/ha produced under both cropping system in Ibadan were similar which indicated that intercropping okra with Jatropha at its early stage will not affect the yield of okra plant (Makinde et al., 2020). Fertilized plants produced more fruits than the control plots even though treated plants had similar results in both locations. Fruit yield of okra was similar in monocrop and intercrop in both locations even though monocrop slightly had higher values. Yield was enhanced by fertilizer application in both locations relative to the unfertilized plants. According to Molik et al., (2016), optimum crop performance is usually affected by inadequate availability of essential nutrients indicating the superiority of fertilized plants over non-fertilized and poorly fertilized ones in term of growth and subsequent yield. Meanwhile, in Ikenne, highest fruit yield was from okra raised with NPK fertilizer and in combination with organic type as a result of the initial nutrient release from the inorganic source and subsequent release by the organic source to ensure consistent supply of nutrient for crop growth and fruiting (Mishra et al., 2020). However, there was no significant interaction between the cropping system and type of fertilizer applied except with the number of fruits/ha in Ikenne.

Table 5: Effect of cropping system and fertilizer sources on the yield components of Okra

\begin{tabular}{|c|c|c|c|c|c|}
\hline \multicolumn{6}{|l|}{ Treatments } \\
\hline & & $\begin{array}{l}\text { Days } \\
\text { to } \\
50 \% \\
\text { flower } \\
\text { ing }\end{array}$ & $\begin{array}{l}\text { Har } \\
\text { vest } \\
\text { dura } \\
\text { tion } \\
\text { (day } \\
\text { s) }\end{array}$ & $\begin{array}{l}\text { Num } \\
\text { ber } \\
\text { of } \\
\text { fruit } \\
\text { s/ha }\end{array}$ & $\begin{array}{l}\text { Fruit } \\
\text { yield } \\
\text { (kg/h } \\
\text { a) }\end{array}$ \\
\hline \multicolumn{6}{|l|}{ Ikenne site } \\
\hline \multicolumn{6}{|l|}{$\begin{array}{l}\text { Cropping } \\
\text { systems }\end{array}$} \\
\hline Sole & & $\begin{array}{l}60.0 \\
8\end{array}$ & 25.08 & $\begin{array}{l}325 . \\
02 a\end{array}$ & $\begin{array}{l}3305 . \\
39\end{array}$ \\
\hline Intercrop & & $\begin{array}{l}59.8 \\
3\end{array}$ & 22.75 & $\begin{array}{l}283 . \\
35 b\end{array}$ & $\begin{array}{l}2791 . \\
36\end{array}$ \\
\hline & & $\mathrm{ns}$ & ns & & ns \\
\hline \multicolumn{6}{|l|}{ Fertilizer } \\
\hline Control & & $\begin{array}{l}59.8 \\
3 a\end{array}$ & $\begin{array}{l}19.83 \\
b\end{array}$ & $\begin{array}{l}183 . \\
34 c\end{array}$ & $\begin{array}{l}1187 . \\
59 c\end{array}$ \\
\hline NPK & & $\begin{array}{l}60.1 \\
7 a\end{array}$ & $\begin{array}{l}26.83 \\
a\end{array}$ & $\begin{array}{l}305 . \\
57 b\end{array}$ & $\begin{array}{l}3459 . \\
67 \mathrm{ab}\end{array}$ \\
\hline Organic & & $\begin{array}{l}60.1 \\
7 a\end{array}$ & $\begin{array}{l}22.17 \\
\mathrm{ab}\end{array}$ & $\begin{array}{l}352 . \\
80 \mathrm{ab}\end{array}$ & $\begin{array}{l}3057 . \\
29 b\end{array}$ \\
\hline $\begin{array}{l}\text { Organic } \\
\text { Inorganic } \\
(50: 50)\end{array}$ & + & $\begin{array}{l}59.6 \\
7 a\end{array}$ & $\begin{array}{l}26.83 \\
a\end{array}$ & $\begin{array}{l}375 . \\
02 \mathrm{a}\end{array}$ & $\begin{array}{l}4488 . \\
94 a\end{array}$ \\
\hline $\mathrm{C}^{*} \mathrm{~F}$ & & ns & ns & $*$ & $\mathrm{~ns}$ \\
\hline
\end{tabular}

\begin{tabular}{lllll}
\hline Ibadan site & & & & \\
$\begin{array}{l}\text { Cropping } \\
\text { systems }\end{array}$ & & & & \\
Sole & 60.0 & 19.83 & 172. & 1354. \\
& 8 & & 23 & 94 \\
Intercrop & 61.0 & 18.67 & 147. & 1057. \\
& 0 & & 23 & 44 \\
& $\mathrm{~ns}$ & $\mathrm{~ns}$ & $\mathrm{~ns}$ & $\mathrm{~ns}$ \\
Fertilizer & & & & \\
Control & 61.8 & 15.17 & 116. & 877.4 \\
& $3 \mathrm{ab}$ & $\mathrm{b}$ & $67 \mathrm{a}$ & $6 \mathrm{~b}$ \\
NPK & 63.0 & 21.00 & 147. & 1007. \\
& $0 \mathrm{a}$ & $\mathrm{a}$ & $23 \mathrm{a}$ & $33 \mathrm{a}$ \\
Organic & 58.8 & 21.00 & 147. & 1202. \\
& $3 \mathrm{ab}$ & $\mathrm{a}$ & $23 \mathrm{a}$ & $94 \mathrm{a}$ \\
Organic & 58.5 & 19.83 & 227. & 1737. \\
Inorganic & $0 \mathrm{~b}$ & $\mathrm{a}$ & $79 \mathrm{a}$ & $03 \mathrm{a}$ \\
(50:50) & & & & \\
& & & & \\
C*F & $\mathrm{ns}$ & $\mathrm{ns}$ & $\mathrm{ns}$ & $\mathrm{ns}$ \\
& & & & \\
\hline
\end{tabular}

\section{CONCLUSION}

\section{Summary and conclusion}

Suitability of intercropping okra with jatropha at the early stage of jatropha growth is never in doubt with the results obtained as growth and subsequent yield of okra was not affected negatively by its intercrop with jatropha. Even though sole okra slightly had better plant height, leaf production, and fruit yield, the result was not significantly different from the intercropped ones. Meanwhile, in both locations, fertilized plants significantly produced more yield than the unfertilized ones in that nutrients are readily available for early flowering and corresponding yield increase. Of all the fertilizer sources investigated, application of organic fertilizer complemented by inorganic type ensures better yield than all other sources. It has the potential to continuously supply nutrient for plant growth and improve soil structure for a sustainable production. Production of okra was better in Ikenne, the rainforest zone than the transitional zone of Ibadan.

\section{Recommendation}

Therefore, intercropping of okra with jatropha should be encouraged with the supply of available nutrient to maximize productivity for sustainable farming.

\section{REFERENCES}

Adeoye, G. O, Sridhar, M.K.C, Adeoluwa,O.O.,and Akinsoji, N.A. (2005).Evaluation of naturally decomposed solid waste from municipal dump sites for their 
manorial value in southwest Nigeria. Journal of Sustainable Agriculture, 26 (4), 143-152.

Adetunji, M.T. 1991. An evaluation of the soil nutrient status for maize production insouth-western Nigeria. Samaru J. Agr. Res. 8:101-113.

Akande, M.O. Oluwatoyinbo, F.I. Makinde, E.A., Adepoju, A.S. and Adepoju, I.S (2010). Response of Okra to Organic and Inorganic Fertilization. Nature and Science ;8(11): 261-266.

Bray, R.M. and L.T. Kurtz. (1945). Determination of total organic $\mathrm{P}$ and available forms of phosphorus in soils. Soil Sci. 59:39-45.

Caroline S., Robert, N, Mireille, MontrejaudVignoles, Olivier, S., Benoit, G, Roland P, Marjorie, D, (2009). Life cycle assessment of biofuels from Jatropha curcas in West Africa: a field study. Bioenergy. (1):3: 197-210

Cotula, L., N. Dyer, and S. Vermeulen. (2008). Fuelling exclusion? The biofuels boom and poor people's access to land.International Institute for Environment and Development, London.

Demographia, (2015): World urban areas (PDF), (11 ${ }^{\text {th }}$ ed.). Retrieved March 2015.

FFD (Federal Fertilizer Department), 2012: Fertilizer use and Management Practices for Crops in Nigeria. Produced by federal ministry of Agricultue and Rural Development. Chude, V.O., Olayiwola, S.O., Dauda, C., Ekeoma, A., (Eds). Abuja, Nigeria. Pp 40-41

Geply, O.A; Baiyewu, R.A; Salaudeen, G.T; Adeleke, T.O; Adegoke, I.A and Oladoja, B.V (2011). Effects of Intercropping Jatropha curcas on growth and yield of Arable crops (Maize and Vegetable). Journal of Research in Forestry, Wildlife and Environment.3:(2)79-84

Ijoyah, M.O. and U.A. Usman, (2013). Okra: A Potential Intercrop For Farmers In Nigeria. Journal of Global Biosciences ISSN 2320-1355 Vol. 2(6), 2013, pp. 222$235 \mathrm{http}: / /$ mutagens.co.in

Kumar, V, Saikia, J and Nath, D.J. (2017). Effect of Integrated Nutrient management on Growth, Yield and Quality of Okra. Intl. Journal of Chemical Studies. 5(5): 2001-2003.

Makinde, A.I, Okunade R..F, Oluwafemi, M.O, Alabi,B.A, Adedeji, J.A And Ayodele, S.Y (2020). Effect Of Okra Spacing On The Growth And Yield Of Okra (Abelmoschus esculentus L. Moench) In a Jatropha -Okra Intercrop. International Journal of Research and Scientific Innovation. Vol.
VII, Issue VIII, August 2020.

ISSN

2321-2705: pp 236- 239.

Makinde, E.A., A.A. Agboola, and F.I. Oluwatoyinbo. (2001). The effects of organic and inorganic fertilizers on the growth and yield of maize in a maize-melon intercrop. Moor J. Agr. Res. 2:15-20.

Makinde E. A., Salau, A. W. \& Ayoola, O. T. (2015) Regrowth Ability and Nutrient Uptake of Amaranthus as Affected by Fertilizer Level. International Journal of Vegetable Science, 21:5, 429-440, DOI: $10.1080 / 19315260.2014 .887598$

Mishra, B, Sahu, G.S, Tripathy, P., Mohant, S and Pradhan, B (2020). Impact of organic and inorganic fertilizers on growth, yield, nutrient uptake and soil fertility in okra (Abelmoschus esculentus (L.) Moench) cv. Pusa A-4. The Pharma Innovation Journal 9(7): 210-213

Molik, A. Zainab, Eluwa, C. Vincent; Oluwatobi, S. Ayodele Lakwannum, Gayus Y; Olorunmaiye, $\quad$ S. Kehinde, (2016). Effects of Organic and Inorganic Fertilizers on the Yield Components of NH-Ae 47-4 Variety of Okra. J. Appl. Sci. Environ. Manage. 20(2): 269-271.

National Horticultural Research Institute (NIHORT) (1985). Effects of spacing and different rates of nitrogen fertilizer on the seed yield of Okra. NIHORT Vegetable Programme Annual Report: pp 45-47

Okigbo, B.N. (1982) Farming system research, An overview of its definitions, concepts and scope. Paper presented at the training workshop on farming system research NIFOR, Benin.

Olawuyi O.J, Babatunde F.E, Akinbode O.A, Odebode A.C, Olakojo, S.A. (2010). Influence of Arbuscular Mycorrhizal and NPK Fertilizer on the Productivity of Cucumber (Cucumis sativus). Proceedings of the 44th Annual Conference of Agricultural Society of Nigeria. Held at Ladoke Akintola University of Technology

(LAUTECH), between 18th-22nd October, 2010.

Olawuyi O. J., Ezekiel-Adewoyin D. T., Odebode, A. C., Aina. D. A. and Esenbamen. G (2012). Effect of arbuscular mycorrhizal (Glomus clarum) and organomineral fertilizer on growth and yield performance of okra

(Abelmoschus esculentus). African 
Journal of Plant Science Vol. 6(2), pp. 84-88.

Olasantan, F.O and Salau,A.W (2008). Effect of Pruning on Growth, Leaf yield and Pod yields of Okra. The Journal of Agricultural Science. Vol. 146, Issue 1: 93-102.

Omotoso, S. O., Fawole, F. O, Aluko, M and Kehinde-Fadare, A. F, (2018). Growth and yield of two okra (Abelmoschus esculentus L. Moench) varieties as affected by organic fertilizer grown on an Oxic Paleustalf in Ekiti State. Global Advanced Research Journal of Agricultural Science (ISSN: 2315-5094) Vol. 7(4): 137-144.

Ramert, B. (2002). "The use of mixed specie cropping to manage pests and diseases.Theory and aparactice, UK Organic Research, 2002," in Proceedings of the COR Conference, Aberystwyth, UK.

Ravi Kant, K. and Surjeet S., (2013). Effect of different Fertilizers on the Growth of Jatropha curcas Seedlings. Int. J. Chem. Sci.: 11(1): 487-502

Robert P. (2013): Nitrogen. Retrieved from www.nofa.org/soil/htm/nitrogen.p

Seran, T.H., \&Brintha, I. (2009). Biological and economic Efficiency of radish (Raphanus sativusL.) intercropped with vegetable amaranthus (Amaranthus tricolor L.). The Open Horticulture Journal, 2, 17-21.
Silwana, T.T and Lucas, E.O (2002). Response of Okra seed crop to varying inter-row and intra-row spacings. Journal of Agricultural Science. 138: 193-200.

Statistical Analysis System (SAS). (1990). Statistical analysis system SAS/STAT users' guide. Ver. 6, 4th ed. Cary, NC: SAS Institute.

Smyth, A.J. and R.F. Montgometry (1962). Soils and land use in central western Nigeria. $\begin{array}{ll}\text { Ibadan } & \text { Government } \\ \text { Printer, } 265 \text { pp. } & \end{array}$

Temnotfo L. M and Henry, R. M. B. (2017). CropWeed Relationships in Okra [Abelmoschus esculentus (L.) Moench], Soybean (Glycine max L.) and Maize (Zea mays L.) in the Middleveld of Swaziland. American Journal of Agriculture and Forestry. 5(4): 73-83

Usman, S.D. (2001). Seed production and quality of okra as affected by sowing time. Seed Research, 29 (1), 47-51.

Wolfe, M. S. (2000). "Agriculture: crop strength through diversity," Nature 406(6797): 681-682. 